Senka Božić-Vrbančić

\section{Tarara: Maori i Hrvati na Novom Zelandu}

Zagreb: Naklada Jesenski i Turk, 2018, 295 str.

DOI: https://doi.org/10.11567/met.35.1.5

Knjiga Tarara: Maori i Hrvati na Novom Zelandu prijevod je knjige objavljene 2008., izdavača Otago University Pressa. U izvorniku knjiga ima i drugi podnaslov: sjećanje, pripadanje, identitet, koji nije uključen u hrvatski prijevod. Knjiga je rezultat višegodišnjega istraživačkog rada autorice Senke Božić-Vrbančić tijekom doktorskog studija na Sveučilištu u Aucklandu na Novom Zelandu.

Kroz razmatranje različitih etnografskih terena, "polja smole na novozelandskom Far Northu i nekoliko malih dalmatinskih sela u podnožju planine Biokovo na hrvatskoj obali Jadranskog mora« (str. 10), što i sama autorica ističe, knjiga daje prikaz odnosa Maora, autohtonog stanovništva Novoga Zelanda, i doseljenih $\mathrm{Hr}-$ vata kroz društveni i povijesni kontekst (kraj 19. i prva polovina 20. stoljeća) koji je doveo do njihova »susreta « i koji je taj odnos formirao, kreirajući ujedno i maorsko-hrvatski identitet. Bliskost kontakta Maora i Hrvata iščitava se i iz naslova knjige jer je Tarara maorski naziv za Hrvate, prvenstveno Dalmatince.

Knjiga je, uz uvodni dio naslovljen »Počeci«, podijeljena na dva dijela koja su strukturirana kroz sedam poglavlja, a svako poglavlje kroz nekoliko potpoglavlja. Prvi dio »Politike identiteta kolonijalnog Novog Zelanda « sastoji se od dva poglavlja, »'Nauči koristiti tijelo' - Maori na koloni- jalnom Novom Zelandu «i »'Nauči koristiti tijelo' - Hrvati na kolonijalnom Novom Zelandu«. Drugi dio »Prostori, sjećanja, identiteti« uz »Uvod « sastoji se od pet poglavlja: »Narativi o poljima smole kao domu«, »Maori i Tarare na poljima smole«, »'Na kraju krajeva, ja sam djelomice Maorka, djelomice Dalmatinka, ali iznad svega ja sam Novozelanđanka'«, »Posjećivanje prošlosti: priče o kauri smoli« $\mathrm{i} »$ Proslava zaborava: bikulturalizam na Novom Zelandu«.

Autorica nas, naslanjajući se na Ernesta Laclaua i Chantal Mouffe (1985), u uvodnom dijelu »Počeci«, uz opis poticaja za istraživanje i nastanak knjige te pregled poglavlja, uvodi u okvir svoga rada kojim pristupa prošlosti i povijesti (sjećanjima), a koja kroz osjećaj pripadanja sudjeluju u procesu konstrukcije identiteta. Analizirajući različitu građu i izvore, uključene u službenu povijest Novog Zelanda, ali i one isključene iz kolektivne memorije koje Foucault naziva kontrasjećanje, odnosno »podređenim znanjem«, Senka Božić-Vrbančić sagledava »kako su sjećanja na prošlost i vrijeme iskopavanja smole konstruirana i rekonstruirana tijekom vremena«, kao i »način na koji su te konstrukcije mobilizirale pojedine identitetske formacije na Novom Zelandu « (str. 18).

U prvom poglavlju »'Nauči koristiti tijelo' - Maori na kolonijalnom Novom Zelandu « kroz institucionalni okvir Suda za domorodačku zemlju i domorodačke škole autorica analizira načine represije i discipliniranja odnosno isključivanja i uključivanja maorskog stanovništva diskurzivnim praksama unutar kolonijalnoga novozelandskog društva kraja 19. i počet- 
ka 20. stoljeća, koji su doveli do odlaska Maora na polja smole Far Northa društveno ih pozicionirajući na samo dno ispod drugih kopača smole, koji su bili klasificirani kao »talog društva« (str. 56).

Drugo poglavlje »'Nauči koristiti tijelo' - Hrvati na kolonijalnom Novom Zelandu « započinje analizom konteksta iseljavanja Hrvata (Dalmatinaca) u potrazi za boljim životom na kraju 19. stoljeća iz područja Hrvatske koja su bila u sklopu Austro-Ugarske. Isto tako, Senka Božić-Vrbančić analizira kontekst doseljavanja Hrvata na Novi Zeland i dolaska na polja smole te kontakta s Maorima, ističući kako je »Njihov odnos bio oblikovan političkim, ekonomskim i društvenim snagama koje su povezivale polja smole sa širim interesima kolonijalnih sila« (str. 87). Ovo poglavlje daje sliku pozicioniranja Hrvata u novozelandskom društvu i promjene pozicioniranja, pod utjecajem kompleksnih odnosa moći u globalnome međuimperijalnom (Prvi svjetski rat) i kolonijalnome novozelandskom kontekstu.

Treće poglavlje »Narativi o poljima smole kao domu « kroz osobna sjećanja Maora i Hrvata prikazuje kako su njihovo društveno marginaliziranje (isključivanje) i izmještanje na polja smole, koja su doživljavali kao »dom bez doma « (str. 108), utjecali na konstrukciju njihova identiteta, imaginaciju onoga što su nazivali domovinom, ali i na povezivanje tih dviju grupa i stvaranje »novog doma na poljima smole« (str. 110).

Autorica u četvrtom poglavlju "Maori i Tarare na poljima smole« kroz priče potomaka Hrvata i Maora daje pogled na utjecaj promjena u političkome, ekonomskom i društvenom kontekstu (djelovanje režima moći) na promjene pozicioniranja unutar novozelandskog društva (isključivanje i uključivanje) i procese identifikacije Maora i Hrvata te njihovih potomaka i na oblikovanje njihovih odnosa koje su oni inicijalno doživljavali kao sličnost kultura.

U petom poglavlju »'Na kraju krajeva, ja sam djelomice Maorka, djelomice Dalmatinka, ali iznad svega Novozelanđanka'« Senka Božić-Vrbančić propituje »način na koji su pojedinci, potomci maorsko-hrvatskih predaka, stvorili vlastiti identitet unutar heterogene diskurzivne prakse koja je djelovala na Novom Zelandu, te kako su doživjeli hibridizaciju identiteta i odnose moći« (str. 170). Kroz dvije priče (Miri Simich i Mira Szászy) pokazuje kako artikulacija identiteta različitim diferencijacijama (klasnim, rodnim i etničkim) stvara »različite interpretacije toga što znači biti Maor-Hrvat na Novom Zelandu « (str. 191).

Šesto poglavlje »Posjećivanje prošlosti: priče o kauri smoli« donosi analizu muzeja kao »mjesta sjećanja« prema konceptu Pierrea Nore (1996). U tom kontekstu, analizirani muzeji reprezentiraju sjećanje na kopanje i polja kauri smole kao dio povijesti Novoga Zelanda i dio povijesti koja je uključena u konstrukciju maorsko-hrvatskog identiteta. Autorica analizira različite reprezentacije; s jedne strane, to je javni Kauri muzej u Matakoheu koji zauzima dominantnu, službenu poziciju reprezentiranja, a s druge su to privatni muzeji (Muzej prodavaonice smole Jurlinove obitelji i Yelashev muzej polja smole), koji zauzimaju dominiranu poziciju reprezentacije. Nasuprot Nori, koji razdvaja dominantno i dominirano mjesto sjećanja, 
autorica upozorava na njihove međuodnose protokom značenja te ističe kako »svaki od njih na svoj način koristi kauri smolu kao konstitutivni element u oblikovanju kolektivnog identiteta [i kako] u svakom od njih priča o kauri smoli postaje mjesto društvene borbe « (str. 221).

U završnom, sedmom poglavlju »Proslava zaborava: bikulturalizam na Novom Zelandu« Senka Božić-Vrbančić govori o diskurzivnom pomaku s kolonijalnoga (koji isključuje i Maore i Hrvate te oblikuje njihov kontakt) u postkolonijalni (bikulturalistički) diskurs koji uključuje različitost i njeno pozitivno vrednovanje te postaje i službena politika Novoga Zelanda. No autorica naglašava kako on u sebi nosi i skrivenu traumu kolonijalnog vremena. Analizirajući različite kulturne prakse (Muzej Novoga Zelanda Te Papa Tongarewa, film Iskrivljeni engleski i proslava Tarara dana), pokazuje kako je taj novi diskurzivni okvir utjecao na konstrukciju i reprezentaciju identiteta te pozicioniranje Maora i Hrvata u novozelandskome bikulturnom društvu, što »oslikava kompleksnu međuigru odnosa moći koja je povezana $\mathrm{s}$ promjenama $\mathrm{u}$ procesu građenja nacije na kolonijalnom Novom Zelandu« (str. 229).
Knjiga Tarara: Maori i Hrvati na Novom Zelandu, bez obzira na teorijsku kompleksnost, vrlo je čitko i vrijedno štivo. Uz analizu bogate i raznovrsne građe ona daje novi i drugačiji pogled na hrvatske iseljenike i njihove potomke na Novom Zelandu usredotočujući se na politički, ekonomski i društveni kontekst kolonijalnoga i postkolonijalnoga novozelandskog društva koji je utjecao na veze Hrvata (Dalmatinaca) s Maorima kao autohtonim stanovništvom Novoga Zelanda. Knjiga je također vrijedan primjer mogućnosti pomaka $\mathrm{u}$ istraživanjima hrvatskog iseljeništva s pretežno povijesnog pregleda iseljavanja i aspekta »domovine« koja se fokusiraju na oblike okupljanja i »čuvanja« identiteta iseljenika, prema interdisciplinarnom pristupu koji ocrtava kompleksnu diskurzivnu mrežu koja utječe na procese identifikacije te reprezentacije i pozicioniranja unutar društva, posebno u kontekstu širenja institucionalnoga znanstvenog, ali i političkog interesa spram iseljeništva i potomaka iseljenika u Hrvatskoj.

\section{Viktorija Kudra Beroš}

Institut za migracije i narodnosti, Zagreb 